\title{
Effect of iron depletion on cell-wall antigens of Candida albicans
}

\author{
T. R. PAUL, S. N. SMITH and M. R. W. BROWN*
}

\section{Microbiology Research Group, Pharmaceutical Sciences Institute, Aston University, Aston Triangle, Birmingham B4 7ET}

\begin{abstract}
Summary. Cell walls were isolated from stationary-phase cultures of Candida albicans grown at $25^{\circ} \mathrm{C}$ or $37^{\circ} \mathrm{C}$, in iron-depleted and iron-sufficient conditions. Proteins solubilised from cell-wall fractions were separated by sodium dodecyl sulphatepolyacrylamide gel electrophoresis. Approximately 40 protein bands were detected by Coomassie blue staining in all wall extracts, regardless of temperature or other growth condition. Sera from patients with oral or systemic candidosis, from whom the isolates were obtained, and pooled normal human serum were examined for the presence of IgG and IgM antibodies to cell-wall proteins by Western blotting. Patient sera recognised more antigens than pooled normal human serum. In particular, an antigen of $44 \mathrm{kda}$ was detected by IgG antibodies in the sera of patients and two antigens of 41 and $14 \mathrm{kda}$ were detected by their IgM antibodies when the sera were used as probes against walls from iron-depleted cells, but not from iron-sufficient cells, grown at $25^{\circ} \mathrm{C}$. Two antigens of 45 and $40 \mathrm{kda}$ were detected by IgM antibodies in the sera of patients tested against walls from iron-depleted but not from ironsufficient cells grown at $37^{\circ} \mathrm{C}$. IgG antibodies did not distinguish between these wall preparations from cells grown at $37^{\circ} \mathrm{C}$. These results suggest that the specific cell-wall proteins induced during growth in iron-depleted conditions, as well as other proteins, were immunogenic and were recognised by the patients' antibodies.
\end{abstract}

\section{Introduction}

The fungal cell wall plays an important role in interactions with host defences during infection. Studies of antigenic variability in Candida albicans have shown that surface antigen expression varies among Candida strains (Hasenclever and Mitchell, 1961; Poulain et al., 1982, 1985) and during growth of the yeast phase in vitro (Ballou, 1976; Manning and Mitchell, 1980; Brawner and Cutler, 1984, 1986; Chaffin et al., 1988; Sundstrom et al., 1988) and in vivo (Hopwood et al., 1986). Poulain et al. (1983) used polyclonal sera to show that a single strain of $C$. albicans may undergo antigenic variation during infection. This dynamic expression of surface antigens may be influenced by nutritional and environmental factors and may shed some light on the role of antibody in candida infections (Mouraud and Friedman, 1968) and other microbial infections (Brown and Williams, 1985).

C. albicans is an opportunist, dimorphic yeast. As a commensal the organism is believed to exist

Received 13 June 1988; accepted 2 Aug. 1988.

* Correspondence should be sent to Professor M. R. W. Brown. primarily in the yeast phase (Simonetti and Stripoli, 1973) while the mycelial phase is expressed during invasive colonisation of the host (Saltarelli et al., 1975; Odds, 1979). It is well known that the withholding of iron constitutes an important component of mammalian host defences against infection (Weinberg, 1971, 1984; Finkelstein et al., 1983; Griffiths, 1983). Iron is relatively unavailable for microbial growth in vivo, and is mainly located intracellularly in haemoglobin and ferritin. Extracellularly, the iron-binding glycoproteins, transferrin (Aisen and Listowsky, 1980) and lactoferrin (Querinjean et al., 1971), ensure that the level of free ionic iron is too low for microbial growth (Bullen, 1981; Griffiths, 1983; Weinberg, 1984). For growth and survival in vivo, $C$. albicans must have a mechanism for the acquisition of iron from its host. To adapt to an iron-restricted environment, pathogenic micro-organisms may synthesise low molecular weight iron-chelating compounds called siderophores and induce envelope receptors for the uptake of iron-siderophore complexes (Neilands, 1981, 1982). These high-affinity iron transport systems can remove iron from the host iron-binding proteins and enable the pathogen to multiply in the 
iron-restricted environment of the host. Recent studies have provided direct evidence that pathogenic bacteria express iron-regulated outer-membrane proteins when grown in vivo (Griffiths et al., 1983; Brown et al., 1984; Brown and Williams, 1985; Shand et al., 1985). Such findings stress the importance of studying the physiology and antigenicity of cells grown in conditions of iron-deprivation.

The ability of $C$. albicans to sequester iron in vivo and the effects that an iron-restricted environment may have on its surface structure and properties is not known. With the increasing importance of $C$. albicans as a serious pathogen (Chandler, 1985; Sobel, 1985) a better understanding of the mechanisms of pathogenicity is needed to improve diagnostic, therapeutic and prophylactic measures. We have investigated the effect of iron-depletion on cell-wall proteins of clinical isolates of $C$. albicans by sodium dodecyl sulphate-polyacrylamide gel electrophoresis(SDS-PAGE) and Western blotting. In addition, specific cell-wall proteins induced in iron-depleted conditions from a number of Candida strains, were probed with sera from normal individuals and from patients with superficial and systemic candidosis.

\section{Materials and methods}

\section{C. albicans strains}

C. albicans strain AU1, isolated from a patient with a superficial candida infection, and strain AU2, isolated from a patient with proven systemic candidosis, were kindly provided by $\mathrm{Mr} \mathrm{D}$. Sinfield, Department of Pathology, Hackney Hospital, London. Strain OMC3, isolated from a patient with oral candidosis, was kindly donated by $\mathrm{Mr}$ J. Hamburger, Oral Medicine Clinic, General Hospital, Birmingham. All strains were identified by Dr C. Fraser, Candida Typing Unit, Mycological Reference Laboratory, Colindale, London.

\section{Removal of iron from medium}

Asparagine (Sigma) $1 \% \mathrm{w} / \mathrm{v}$ and glucose (BDH) $1.25 \% \mathrm{w} / \mathrm{v}$ were dissolved in double distilled water to $1 \mathrm{~L}$ and the solution pumped through a column of Chelex100 ion-exchange resin (Bio-Rad, Watford, Herts) at a rate of $2.45 \mathrm{ml} / \mathrm{min}$ for $36 \mathrm{~h}$ (Kadurugamuwa et al., 1987). To the iron-depleted eluate was added $0.045 \mathrm{M}$ $\left(\mathrm{NH}_{4}\right)_{2} \mathrm{SO}_{4}, 0.085 \mathrm{M} \mathrm{NaCl}, 1.4 \mathrm{mM} \mathrm{K} \mathrm{HPO}_{4}, 0.8 \mathrm{mM}$ $\mathrm{MgSO}_{4} \cdot 7 \mathrm{H}_{2} \mathrm{O}$ (Analytical Reagents, BDH) and $0.67 \mathrm{mM}$ L-methionine (Sigma), $\mathrm{pH} 4 \cdot 5$. After autoclaving at $115^{\circ} \mathrm{C}$ for $20 \mathrm{~min}$, the medium was supplemented with $0.4 \mathrm{mM}$ Biotin (BDH) from a stock solution sterilised by filtration through a $0 \cdot 22-\mu \mathrm{m}$ membrane filter (Millipore). Iron- depleted chemically defined medium ( $\mathrm{Fe}-\mathrm{CDM}$ ) contained $0.35 \pm 0.15 \mu \mathrm{M}$ iron as determined by atomic absorption spectrophotometry (Perkin-Elmer, Beaconsfield, Bucks). Iron-sufficient chemically defined medium $(\mathrm{Fe}+\mathrm{CDM})$ was prepared by the addition of $100 \mu \mathrm{M}$ $\mathrm{FeSO}_{4} \cdot 7 \mathrm{H}_{2} \mathrm{O}$ to $\mathrm{Fe}-\mathrm{CDM}$. Glassware was treated as described previously (Kadurugamuwa et al., 1987).

\section{Culture conditions}

All strains were maintained on Sabouraud Dextrose Agar (Oxoid) slopes. Cells washed from a slope were inoculated into $125-\mathrm{ml}$ Erlenmeyer flasks containing $25 \mathrm{ml}$ of $\mathrm{Fe}-\mathrm{CDM}$. After shaking at $150 \mathrm{rpm}$ for $48 \mathrm{~h}$ at $25^{\circ} \mathrm{C}$, a portion of culture was transferred to similar flasks containing fresh $\mathrm{Fe}-\mathrm{CDM}$. Cultures serially transferred from this second culture were used for experimental purposes as follows: stationary phase cells were harvested by centrifugation at $2500 \mathrm{~g}$ for $5 \mathrm{~min}$, washed twice and resuspended in double distilled water; the cells were reinoculated into fresh prewarmed $\mathrm{Fe}-\mathrm{CDM}$ at a concentration of $2 \times 10^{6}$ cells $/ \mathrm{ml}$. Yeast-phase organisms were obtained by shaking flasks at $150 \mathrm{rpm}$ at $25^{\circ} \mathrm{C}$ or $37^{\circ} \mathrm{C}$.

\section{Preparation of cell walls}

Stationary phase yeast cells were harvested by centrifugation, washed in cold double distilled water and resuspended in $1 \mathrm{~mm}$ phenylmethylsulphonyl fluoride (PMSF). An equal volume of glass beads $(0.45 \mathrm{~mm}$; Sigma) was added and the suspension disrupted by blending on a vortex mixer for 3 min with intervals on ice. At least $95 \%$ cell breakage was observed by light microscopy. Walls were sedimented by centrifugation and washed several times in $1 \mathrm{mM}$ PMSF (Chaffin and Stocco, 1983).

\section{Serum samples}

A single serum sample was collected by venepuncture from the patients from whom $C$. albicans strains AU2 and OMC3 were obtained. Normal human serum was collected from seven healthy donors and pooled.

\section{Electrophoresis}

Cell-wall proteins were added to equal volumes of sample buffer, denatured at $100^{\circ} \mathrm{C}$ and separated by SDSPAGE on $12 \%$ gels in a discontinuous buffer system as described by Lugtenberg et al. (1975). Gels were either stained with Coomassie blue or used for Western blotting.

\section{Western blotting}

The proteins separated by SDS-PAGE were transferred on to nitrocellulose sheets as described by Towbin et al. (1979). Blotting was performed in a transblotting 
chamber (Bio-Rad) for $1 \mathrm{~h}$ at a constant voltage of $90 \mathrm{~V}$ followed by $16 \mathrm{~h}$ at $50 \mathrm{~V}$ in ice-cold buffer ( $\mathrm{pH} \mathrm{8.3)}$ containing $25 \mathrm{~mm}$ Tris, $192 \mathrm{~mm}$ glycine and methanol $20 \% \mathrm{v} / \mathrm{v}$. After transfer, the nitrocellulose sheets were cut vertically into strips and washed with gentle shaking for $1 \mathrm{~h}$ at $37^{\circ} \mathrm{C}$ in a solution containing Tween-20 $0.3 \% \mathrm{v} / \mathrm{v}$, $\mathrm{NaCl} 0.9 \% \mathrm{w} / \mathrm{v}$ and $0.01 \mathrm{M}$ Tris- $\mathrm{HCl}$ (pH 7.4) (TTBS) to block unbound sites on the nitrocellulose. The strips were rinsed six times in $0.01 \mathrm{M}$ Tris- $\mathrm{HCl}$ buffer $(\mathrm{pH} \mathrm{7.4)}$ containing $\mathrm{NaCl} 0.9 \%$ w/v (TBS), then incubated with gentle shaking at $37^{\circ} \mathrm{C}$ for $4 \mathrm{~h}$ in either patient serum or pooled normal serum at a dilution of 1 in 25 in TTBS. The blots were rinsed six times in TBS and incubated with gentle shaking at $37^{\circ} \mathrm{C}$ for $1 \mathrm{~h}$ in alkaline phosphatase-conjugated rabbit anti-human IgG or IgM (DAKO Ltd, High Wycombe, Bucks) at a dilution of 1 in 1000 in TTBS. After rinsing in TBS as described above, the strips were developed by adding a freshly prepared solution containing nitroblue-tetrazolium (Bio-Rad) $0.33 \mathrm{mg} / \mathrm{ml}$ and 5-bromo-4-chloro-3-indoyl phosphate (Bio-Rad) $0.165 \mathrm{mg} / \mathrm{ml}$ in alkaline phosphatase buffer containing $0.1 \mathrm{M}$ Tris, $\mathrm{NaCl} 0.58 \% \mathrm{w} / \mathrm{v}$ and $\mathrm{MgCl} 0.1 \% \mathrm{w} / \mathrm{v}(\mathrm{pH}$ 9.5). After $15 \mathrm{~min}$ the reaction was stopped by immersing the strips in a solution containing $0.02 \mathrm{M}$ Tris and EDTA $0.2 \% \mathrm{w} / \mathrm{v}(\mathrm{pH} 8.0)$.

For detection of glycosylated components with concanavalin $\mathrm{A}$, the washed blots were gently shaken at $37^{\circ} \mathrm{C}$ for $2 \mathrm{~h}$ in the concanavalin A-peroxidase conjugate (Sigma) in TTBS $0.5 \mu \mathrm{g} / \mathrm{ml}$. These blots were visualised after rinsing in TBS by adding a freshly prepared solution containing $\mathrm{H}_{2} \mathrm{O}_{2} \quad 0.01 \% \mathrm{v} / \mathrm{v}$ and 4-chloro-1-naphthol (Sigma) $25 \mu \mathrm{g} / \mathrm{ml}$ in $0.01 \mathrm{M}$ Tris- $\mathrm{HCl}$ (pH 7.4). The 4chloro-1-naphthol was first dissolved in a small amount of methanol and then added to the $\mathrm{H}_{2} \mathrm{O}_{2}$-Tris- $\mathrm{HCl}$ solution. The reaction was stopped by rinsing with water.

\section{Results}

\section{$S D S-P A G E$}

SDS-PAGE of cell walls from each of the three isolates of $C$. albicans grown in the presence and absence of iron revealed similar protein profiles, indicating no interstrain variation. Therefore, strain AU2 was chosen as representative of these isolates. Fig. 1 shows the protein profiles of walls of strain AU2 grown in $\mathrm{Fe}-\mathrm{CDM}$ and $\mathrm{Fe}+\mathrm{CDM}$, stained with Coomassie blue. All the profiles were similar. Approximately 40 bands were observed in each profile. Qualitative differences were not associated with temperature or other growth conditions for these stained preparations.

\section{Recognition of wall antigens in cells grown at $25^{\circ} \mathrm{C}$}

Western blots of electrophoretically separated proteins from each of the three isolates grown in

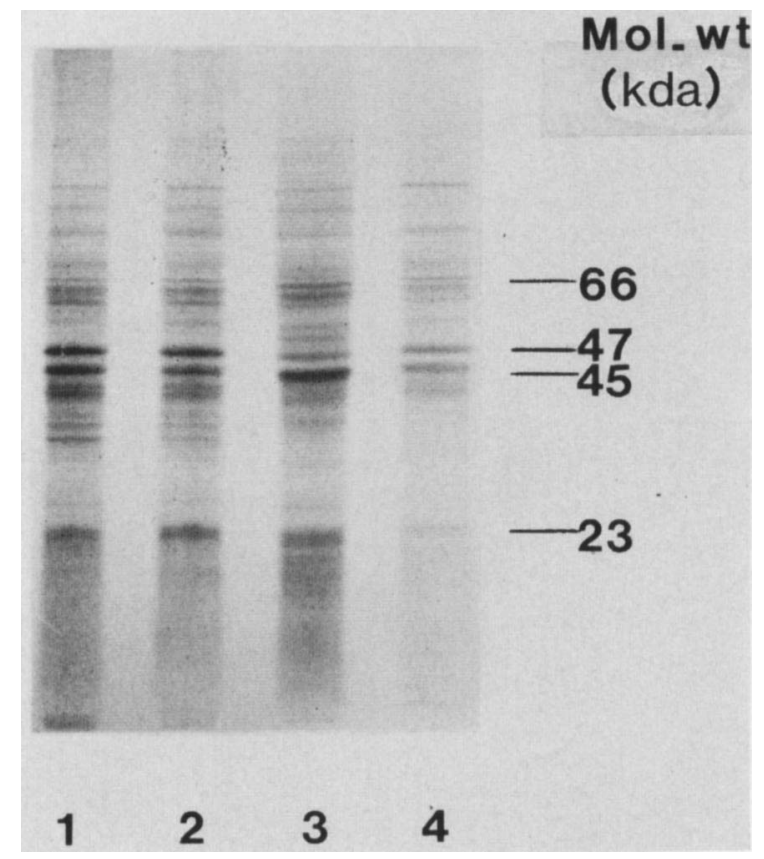

Fig. 1. Protein profiles of cell walls of $C$. albicans strain AU2 separated by SDS-PAGE and stained with Coomassie blue. Track 1, cell walls from cells grown in $\mathrm{Fe}+\mathrm{CDM}$ at $25^{\circ} \mathrm{C}$; track 2 , cell walls from cells grown in $\mathrm{Fe}-\mathrm{CDM}$ at $25^{\circ} \mathrm{C}$; track 3, cell walls from cells grown in $\mathrm{Fe}+\mathrm{CDM}$ at $37^{\circ} \mathrm{C}$; track 4, cell walls from cells grown in $\mathrm{Fe}-\mathrm{CDM}$ at $37^{\circ} \mathrm{C}$.

the presence or absence of iron revealed similar antigenic profiles when treated with serum from patients with oral or systemic candidosis or pooled normal human serum. Therefore, strain AU2 was chosen as representative of these isolates. Figs. 2 and 3 show Western blots of wall proteins from strain AU2 detected with serum from the patient with systemic candidosis and normal human serum. The IgG response was marked by a dense, diffuse staining to the upper portion of each blot (fig. 2). All blots showed similar antigenic profiles. This patient serum revealed two antigens of 44 and $35 \mathrm{kda}$ (track 2), whereas normal serum revealed only the antigen of $35 \mathrm{kda}$ (track 4), in walls of yeasts grown in $\mathrm{Fe}-\mathrm{CDM}$. Neither antigen was detected in walls of yeasts grown in Fe + CDM.

IgM antibodies reacted strongly with an antigen of $47 \mathrm{kda}$ in each blot (fig. 3). Serum from the patient with systemic candidosis revealed three antigens of 45,41 and $14 \mathrm{kda}$ (track 2), whereas normal serum revealed only an antigen of $14 \mathrm{kda}$ (track 4) in walls of yeasts grown in Fe-CDM. IgM antibodies did not reveal any of these antigens in walls of yeasts grown in $\mathrm{Fe}+\mathrm{CDM}$. 


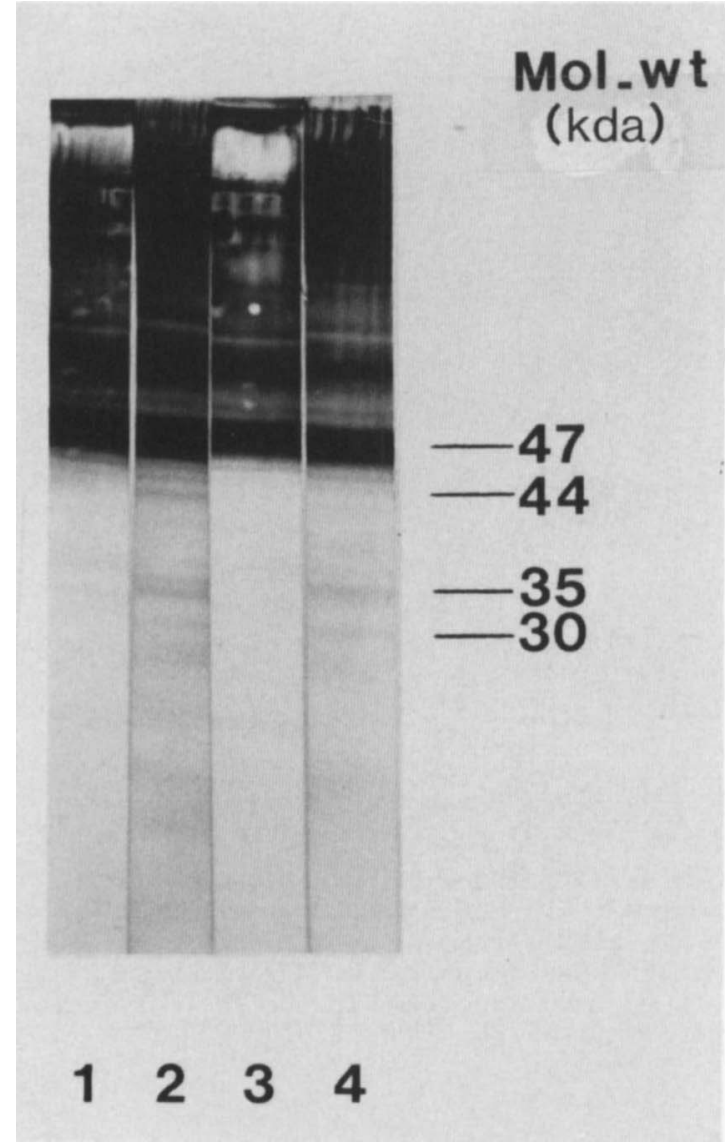

Fig. 2. Western blots of cell walls from cells grown at $25^{\circ} \mathrm{C}$ as described in fig. 1 detected with IgG. Tracks 1 and 2, incubated with patients' serum; tracks 3 and 4 , incubated with pooled normal human serum.

\section{Recognition of wall antigens in cells grown at $37^{\circ} \mathrm{C}$}

The IgG response (fig. 4) was again marked by a dense, diffuse, but less intense staining to the upper portion of each blot. IgG of serum from the patient with systemic candidosis strongly revealed an antigen of $47 \mathrm{kda}$ in walls of yeasts grown in the presence and absence of iron (fig. 4 ; tracks 1 and 2 ), otherwise the antigenic profiles were similar. Although normal serum did not recognise this antigen in walls of yeasts grown in $\mathrm{Fe}+\mathrm{CDM}$, this antigen and three others of 45, 40 and $35 \mathrm{kda}$ were clearly detected in walls of yeasts grown in $\mathrm{Fe}-$ CDM (fig. 4; tracks 3 and 4).

IgM antibodies in the serum of the patient with systemic candidosis reacted strongly with an antigen of $40 \mathrm{kda}$, and revealed an antigen of $55 \mathrm{kda}$ (fig. 5 ; track 2) in walls of yeasts grown in the absence, but not in the presence of iron (track 1). Pooled normal human serum revealed an antigen

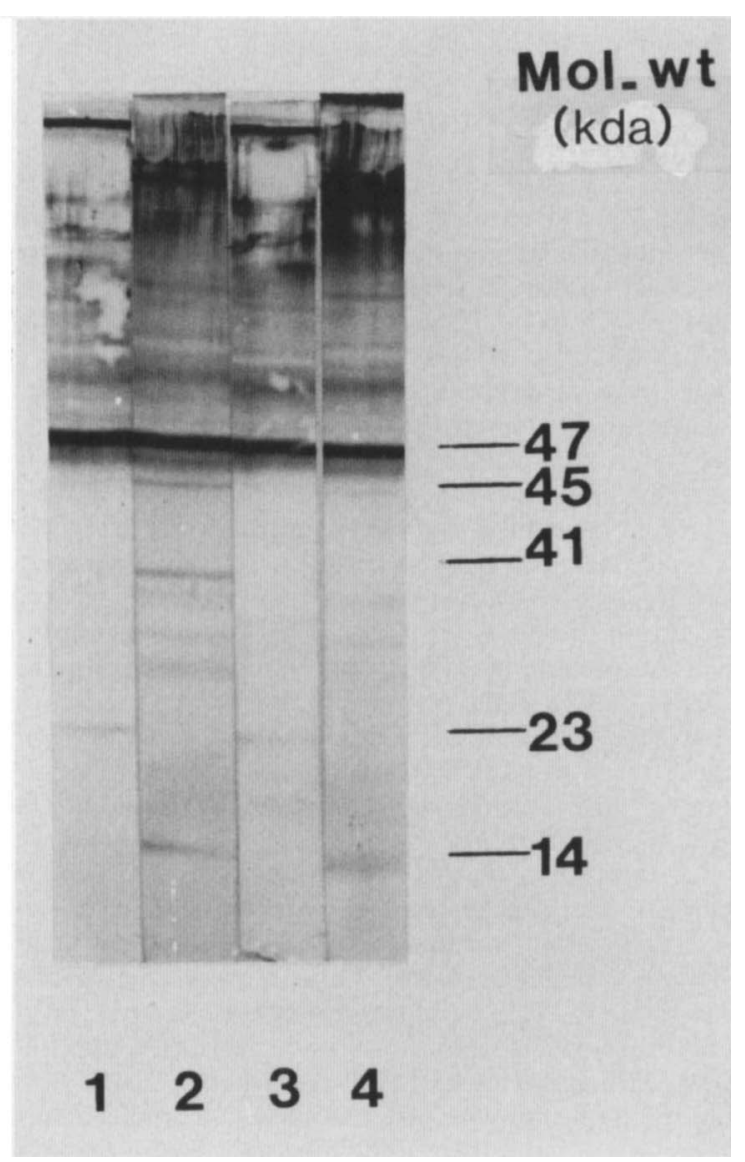

Fig. 3. Western blots of cell walls from cells grown at $25^{\circ} \mathrm{C}$ as described in fig. 1 detected with IgM. Tracks 1 and 2, incubated with patients' serum; tracks 3 and 4 , incubated with pooled normal human serum.

of $43 \mathrm{kda}$ in walls of yeasts grown in the absence, but not in the presence of iron.

\section{Lectin blotting with concanavalin $A$}

Lectin blotting revealed different antigenic patterns in the walls of yeasts grown in the presence and absence of iron, and also at different growth temperatures (fig. 6). Concanavalin A-peroxidase reacted strongly with the antigen of $47 \mathrm{kda}$ in all wall extracts except those obtained from cells grown in $\mathrm{Fe}+\mathrm{CDM}$ at $37^{\circ} \mathrm{C}$ (track 3). The lectin also gave strong reactions with the antigens of 41,35 and $30 \mathrm{kda}$ (track 2) in walls of yeasts grown in $\mathrm{Fe}-$ $\mathrm{CDM}$ at $25^{\circ} \mathrm{C}$, and with an antigen of $19 \mathrm{kda}$ (track 4) in walls of yeasts grown in $\mathrm{Fe}-\mathrm{CDM}$ at $37^{\circ} \mathrm{C}$. Weaker reactions were obtained with other antigens. 


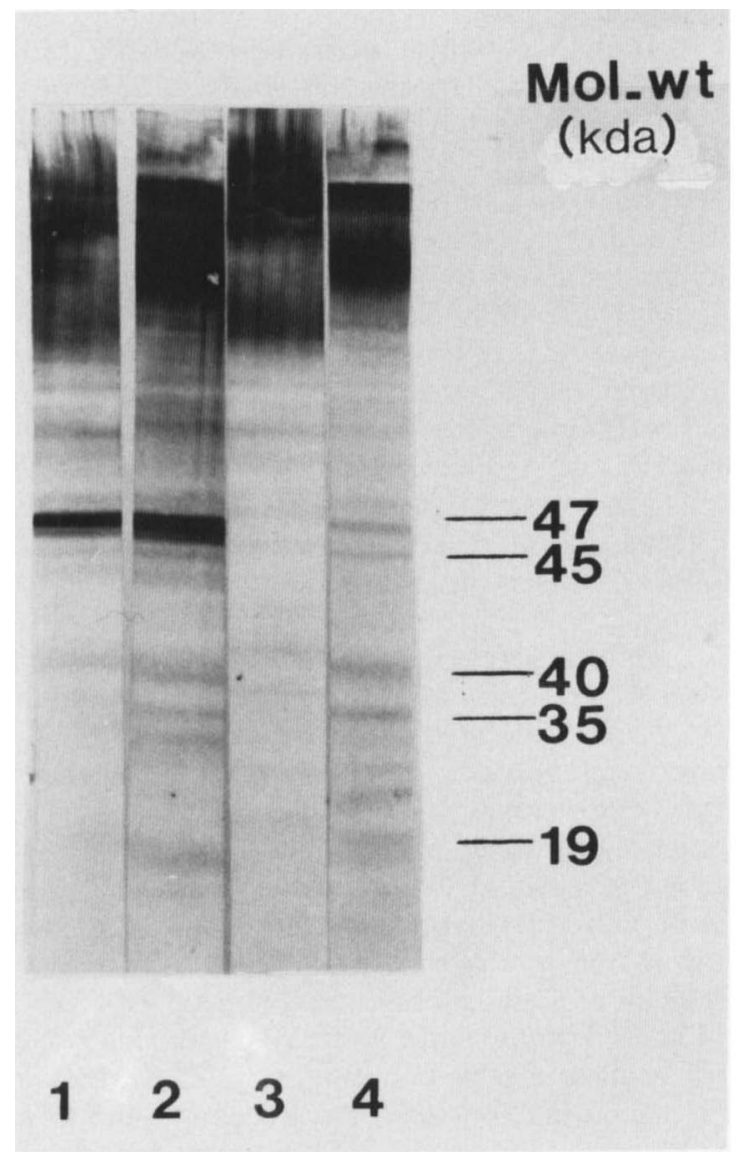

Fig. 4. Western blots of cell walls from cells grown at $37^{\circ} \mathrm{C}$ as described in fig. 1 detected with IgG. Tracks 1 and 2, incubated with patients' serum; tracks 3 and 4 , incubated with pooled normal human serum.

\section{Discussion}

Factors such as growth rate, specific nutrient depletion and age of culture influence the surface composition and properties of bacteria (Brown and Williams, 1985). The role of iron in bacterial infections has received increasing attention (Field et al., 1986; Griffiths, 1987; Hall et al., 1987). Fungal pathogens in host tissue encounter the same iron-restricted environment as bacteria, and iron is an essential nutrient for these organisms too; growth of $C$. albicans is inhibited in vitro in the presence of iron-binding proteins or serum, and this inhibition can be reversed by the addition of iron (Caroline et al., 1964; Esterley et al., 1967; Kirkpatrick et al., 1971; Elin and Wolff, 1973). The mechanism by which $C$. albicans acquires iron when growing in vivo is not known. $C$. albicans

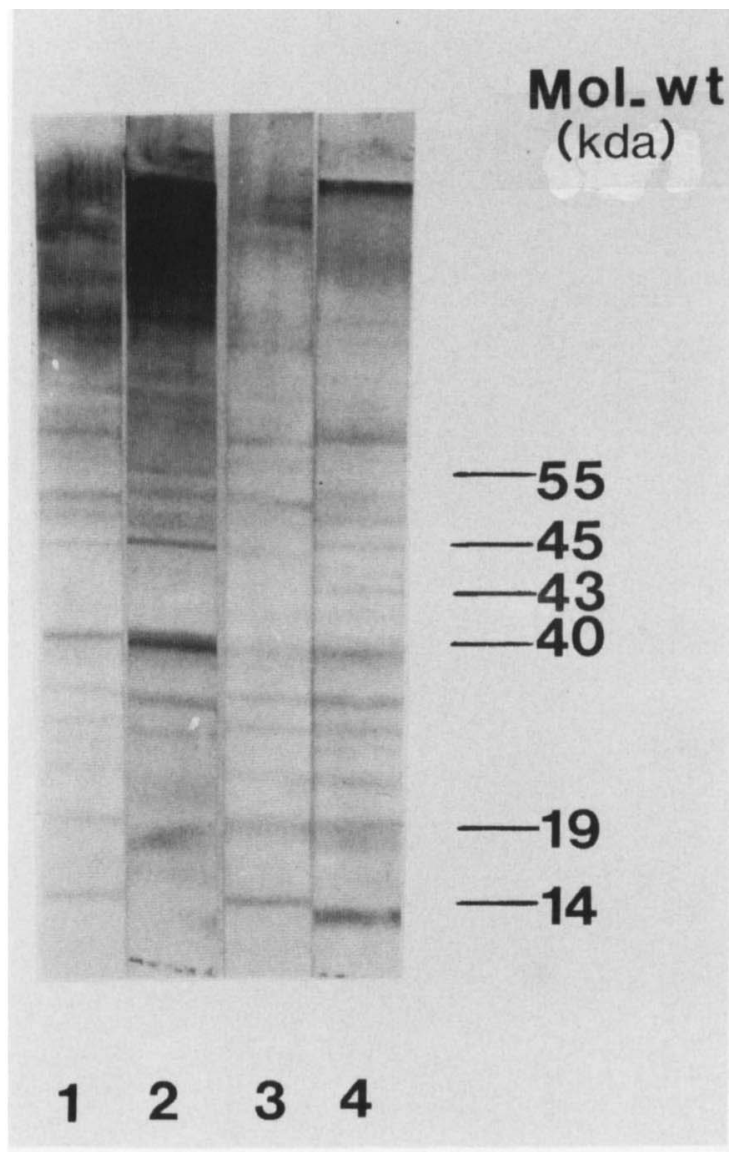

Fig. 5. Western blots of cell walls from cells grown at $37^{\circ} \mathrm{C}$ as described in fig. 1 detected with IgM. Tracks 1 and 2, incubated with patients' serum; tracks 3 and 4 , incubated with pooled normal human serum.

produces siderophores of the hydroxamate-type (Holzberg and Artis, 1983), and certain clinical isolates may produce a phenolate-type siderophore (Ismail et al., 1985). The chemical structures of these chelators and their role, if any, during infection are not known. Similarly, there is no information on the effect of iron-restriction on the biological properties or cell envelope of $C$. albicans.

In the present study, the different growth conditions used had little effect on the expression of protein antigens visualised with Coomassie blue, but differences were revealed by Western blotting. By this technique walls of yeasts grown in the presence and absence of iron were shown to contain a range of proteins recognised as antigens by serum from patients with oral or systemic candidosis. IgG antibodies of the patients' serum reacted strongly with an antigen of $47 \mathrm{kda}$ in walls of yeasts grown 


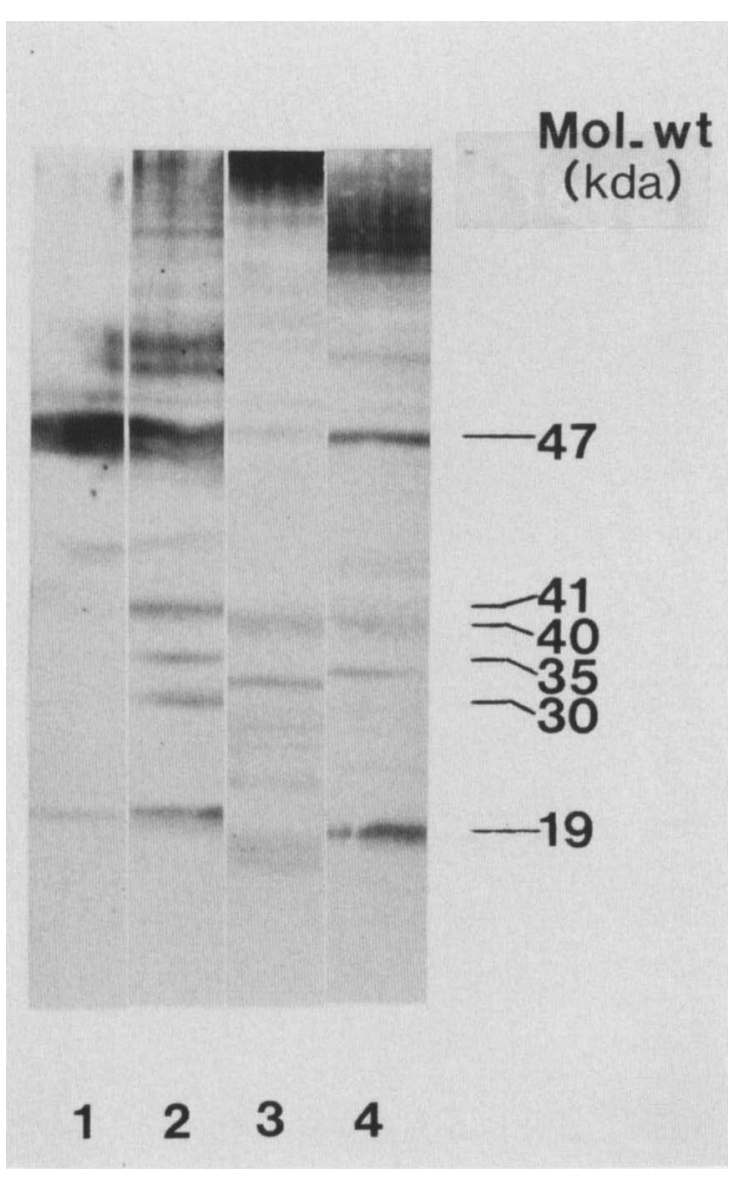

Fig. 6. Western blots of cell walls detected with concanavalin A-peroxidase. See fig. 1 for growth conditions of samples.

in both media at $25^{\circ} \mathrm{C}$ and at $37^{\circ} \mathrm{C}$. This has been described as an immunodominant antigen of $C$. albicans (Matthews et al., 1984). Immunodominant antigens with similar molecular weights (Greenfield and Jones, 1981; Strockbine et al., 1984a, b; AuYoung et al., 1985; Bruneau and Guinet, 1987) may be identical or closely related, since apparent differences in molecular weight may arise through differences in methods of antigen preparation and antibody detection. This antigen appears to be characteristic of systemic candidosis because antibodies to it are rare in sera from uninfected individuals and infrequent in superficially-infected patients (Jones, 1980; Matthews and Burnie, 1988). Matthews et al. (1987) found that $40 \%$ of patients who produced antibody during systemic candidosis responded to an antigen of $60 \mathrm{kda}$ and $92 \%$ responded to an antigen of $47 \mathrm{kda}$. The major antibody response to the latter antigen was predom- inantly of the IgM class. We found that IgG antibodies in patients' serum reacted strongly to this antigen in walls from cells grown at $25^{\circ} \mathrm{C}$ or at $37^{\circ} \mathrm{C}$ but IgM reacted strongly only when cells were grown at $25^{\circ} \mathrm{C}$.

Expression of surface antigens varies among $C$. albicans strains (Hasenclever and Mitchell, 1961; Poulain et al., 1983; Brawner and Cutler, 1986; Chaffin et al., 1988; Sundstrom et al., 1988). They are expressed dynamically as a function of morphological state, growth phase and nutritional factors (Ballou, 1976; Manning and Mitchell, 1980; Brawner and Cutler, 1984, 1986; Hopwood et al., 1986). Brawner and Cutler (1987) characterised two antigens which reacted specifically with monoclonal antibodies and found them to be substituted mannans. These workers compared the intracellular and cell-surface expression of the same two antigenic determinants during growth of $C$. albicans in vitro and in infected mice by electronmicroscopy. Differences between in-vitro and in-vivo antigen expression were noted during early stages of growth. Antigen expression in vitro was confined to the surface layers and to the innermost wall layer of mother cells and hyphae, whereas antigen expression in vivo was concentrated in deeper cell-wall layers on mother cells and germ tubes.

The nutritional state of micro-organisms in vivo is difficult to assess, and may vary from one body site to another, but one may speculate about the nature of the growth-limiting nutrient for various localised sites (Brown, 1977; Brown and Williams, 1985). Hence, it is well established that in many infections the micro-organism is growing in an iron-restricted environment. We have shown that IgG and IgM antibodies from patients' sera and normal human serum revealed marked differences in their recognition of surface antigens in walls from cells grown in iron-rich and iron-depleted media. New proteins expressed in walls from the clinical isolate grown in iron-depleted conditions (but not expressed after growth in iron-rich medium) were immunogenic and were detected by antibodies in the patient's own serum. These new proteins may represent envelope receptors and enzymes involved in the uptake and transport of iron from siderophores. Because the cell surface of C. albicans consists mainly of glycoproteins, we examined the surface proteins for the presence of mannose residues by probing with the lectin, concanavalin A-peroxidase (Reeke et al., 1974). The lectin reacted strongly with specific antigens, many of which were recognised by patients' serum and normal human serum, indicating that these antigens, including those induced in conditions of 
iron-depletion, contained mannose. The significance of these findings in infection remains to be determined. Further studies to characterise these new surface antigens may contribute to a better

\section{REFERENCES}

Aisen P, Listowsky I 1980 Iron transport and storage proteins. Annual Review of Biochemistry 49: 357-393.

Au-Young J K, Troy F A, Goldstein E 1985 Serologic analysis of antigen-specific reactivity in patients with systemic candidiasis. Diagnostic Microbiology and Infectious Disease 3: 419-432.

Ballou C 1976 Structure and biosynthesis of the mannan component of the yeast cell envelope. Advances in Microbial Physiology 14: 93-158.

Brawner D L, Cutler J E 1984 Variability in expression of a cell surface determinant on Candida albicans as evidenced by an agglutinating monoclonal antibody. Infection and Immunity 43: 966-972.

Brawner D L, Cutler J E 1986 Ultrastructural and biochemical studies of two dynamically expressed cell surface determinants on Candida albicans. Infection and Immunity 51 : $327-$ 336.

Brawner D L, Cutler J E 1987 Cell surface and intracellular expression of two Candida albicans antigens during in-vitro and in-vivo growth. Microbial Pathogenesis $2:$ 249-258.

Brown M R W 1977 Nutrient depletion and antibiotic susceptibility. Journal of Antimicrobial Chemotherapy 3: 198-201.

Brown M R W, Anwar H, Lambert P A 1984 Evidence that mucoid Pseudomonas aeruginosa in the cystic fibrosis lung grows under iron restricted conditions. FEMS Microbiology Letters 21 : 113-117.

Brown M R W, Williams P 1985 The influence of the environment on envelope properties affecting survival of bacteria in infections. Annual Review of Microbiology 39: $527-556$.

Bruneau S M, Guinet R M F 1987 Candida albicans and Candida tropicalis antigens studied by SDS polyacrylamide gel electrophoresis and Western Blot. Mykosen 30: 271-280.

Bullen J J 1981 The significance of iron in infection. Reviews of Infectious Diseases 3: 1127-1138.

Caroline L, Taschdjian C L, Kozinn P J, Schade A L 1964 Reversal of serum fungistasis by addition of iron. Journal of Investigative Dermatology 42: 415-419.

Chaffin W L, Stocco D M 1983 Cell wall proteins of Candida albicans. Canadian Journal of Microbiology 29: 1438-1444.

Chaffin W L, Skudlarek J, Morrow K J 1988 Variable expression of a surface determinant during proliferation of Candida albicans. Infection and Immunity 56: 302-309.

Chandler F W 1985 Pathology of the mycoses in patients with the acquired immunodeficiency syndrome (AIDS). Current Topics in Medical Mycology 1: 1-23.

Elin R J, Wolff S M 1973 Effect of $\mathrm{pH}$ and iron concentration on growth of Candida albicans in human serum. Journal of Infectious Diseases 127: 705-708.

Esterley N B, Brammar S R, Crounse R G 1967 The relationship of transferrin and iron to serum inhibition of Candida albicans. Journal of Investigative Dermatology 49: 437-442.

Field L H, Headley V L, Payne S M, Berry L J 1986 Influence of iron on growth, morphology, outer membrane protein composition, and synthesis of siderophores in Campylobacter jejuni. Infection and Immunity 54: 126-132. understanding of the mechanisms involved in the pathogenicity of $C$. albicans.

This work was partly assisted by the Cystic Fibrosis Research Trust and the Medical Research Council.

Finkelstein R A, Sciortino C V, McIntosh M A 1983 Role of iron in microbe-host interactions. Reviews of Infectious Diseases 5: S759-S777.

Greenfield R A, Jones J M 1981 Purification and characterization of a major cytoplasmic antigen of Candida albicans. Infection and Immunity 34: 469-477.

Griffiths E 1983 Availability of iron and survival of bacteria in infection. In: Easmon C S F et al. (eds) Medical Microbiology, vol 3. Academic Press, London, pp 153-177.

Griffiths E 1987 The iron-uptake systems of pathogenic bacteria. In: Bullen $\mathbf{J} \mathbf{J}$, Griffiths $\mathbf{E}$ (eds) Iron and infection: molecular, physiological and clinical aspects. John Wiley and Sons Ltd, Chichester, pp 69-137.

Griffiths E, Stevenson P, Joyce P 1983 Pathogenic Escherichia coli express new outer membrane proteins when growing in vivo. FEMS Microbiology Letters 16: 95-99.

Hall R M, Sritharan M, Messenger A J M, Ratledge C 1987 Iron transport in Mycobacterium smegmatis: occurrence of iron-regulated envelope proteins as potential receptors for iron uptake. Journal of General Microbiology 133: 21072114.

Hasenclever H F, Mitchell W O 1961 Antigenic studies of Candida. I. Observation of two antigenic groups in Candida albicans. Journal of Bacteriology 82: 570-573.

Holzberg M, Artis W M 1983 Hydroxamate siderophore production by opportunistic and systemic fungal pathogens. Infection and Immunity 40: 1134-1139.

Hopwood V, Poulain D, Fortier B, Evans G, Vernes A 1986 A monoclonal antibody to a cell wall component of Candida albicans. Infection and Immunity 54: 222-227.

Ismail A, Bedell G W, Lupan D M 1985 Siderophore production by the pathogenic yeast Candida albicans. Biochemical and Biophysical Research Communications 130: 885-891.

Jones J M 1980 Quantitation of antibody against cell wall mannan and a major cytoplasmic antigen of Candida in rabbits, mice, and humans. Infection and Immunity 30: 78 89.

Kadurugamuwa J L, Anwar H, Brown M R W, Shand G H, Ward K H 1987 Media for study of growth kinetics and envelope properties of iron-deprived bacteria. Journal of Clinical Microbiology 25: 849-855.

Kirkpatrick C H, Green I, Rich R R, Schade A L 1971 Inhibition of growth of Candida albicans by iron-unsaturated lactoferrin: relation to host-defence mechanisms in chronic mucocutaneous candidiasis. Journal of Infectious Diseases 124: 539-544.

Lugtenberg B, Meijers J, Peters R, Van der Hoek P, van Alphen L 1975 Electrophoretic resolution of the "major outer membrane protein" of Escherichia coli $\mathrm{K} 12$ into four bands. FEBS Letters 58: 254-258.

Manning M, Mitchell T G 1980 Strain variation and morphogenesis of yeast and mycelial phase Candida albicans in lowsulfate, synthetic medium. Journal of Bacteriology 142 : 714 719.

Matthews R C, Burnie J P, Tabaqchali S 1984 Immunoblot analysis of the serological response in systemic candidosis. Lancet 2: 1415-1418.

Matthews R C, Burnie J P, Tabaqchali S 1987 Isolation of immunodominant antigens from sera of patients with 
systemic candidiasis and characterization of serological response to Candida albicans. Journal of Clinical Microbiology 25: 230-237.

Matthews R, Burnie J 1988 Diagnosis of systemic candidiasis by an enzyme-linked dot immunoblotting assay for a circulating immunodominant 47-kilodalton antigen. Journal of Clinical Microbiology 26 : 459-463.

Mouraud S, Friedmann L 1968 Passive immunization of mice against Candida albicans. Sabouraudia 6: 103-105.

Neilands J B 1981 Microbial iron compounds. Annual Review of Biochemistry 50: 715-731.

Neilands J B 1982 Microbial envelope proteins related to iron. Annual Review of Microbiology 36: 285-309.

Odds F C 1979 Candida and candidosis. Leicester University Press, Leicester, $\mathrm{p} 198$.

Poulain D, Tronchin G, Lefebvre B, Husson M O 1982 Antigenic variability between Candida albicans blastospores isolated from healthy subjects and patients with Candida infection. Sabouraudia 20: 173-177.

Poulain D, Tronchin G, Vernes A, Popeye R, Biquet J 1983 Antigenic variations of Candida albicans in vivo and in vitro: relationships between $\mathrm{P}$ antigens and serotypes. Sabouraudia 21: 99-112.

Poulain D, Hopwood V, Vernes A 1985 Antigenic variability of Candida albicans. CRC Critical Reviews in Microbiology 12: 223-270.

Querinjean P, Masson P L, Heremans J F 1971 Molecular weight, single-chain structure, and amino acid composition of human lactoferrin. European Journal of Biochemistry 20: $420-425$.

Reeke G N, Becker J W, Cuningham B A, Gunther G R, Wang J L, Edelman G M 1974 Relationships between the structure and activities of concanavalin A. Annals of the New York Academy of Sciences 234: 369-382.
Saltarelli C G, Gentile K A, Mancuso S C 1975 Lethality of Candida Strains as influenced by the host. Canadian Journal of Microbiology 21 : 648-654.

Shand G H, Anwar H, Kadurugamuwa J, Brown M R W, Silverman S H, Melling J 1985 In-vivo evidence that bacteria in urinary tract infection grow under iron-restricted conditions. Infection and Immunity 48: 35-39.

Simonetti N, Stripoli V 1973 Pathogenicity of the form as compared to the $\mathrm{M}$ form in experimentally-induced Candida albicans infections. Mycopathologia et Mycologia Applicata 51: 19-28.

Sobel J D 1985 Epidemiology and pathogenesis of recurrent vulvovaginal candidosis. American Journal of Obstetrics and Gynecology 152: 924-935.

Strockbine N A, Largen M T, Buckley H R 1984a Production and characterization of three monoclonal antibodies to Candida albicans proteins. Infection and Immunity 43: 10121018.

Strockbine N A, Largen M T, Zweibel S M, Buckley H R $1984 b$ Identification and molecular weight characterization of antigens from Candida albicans that are recognised by human sera. Infection and Immunity 43: 715-721.

Sundstrom P A, Tam M R, Nichols E J, Kenny G E 1988 Antigenic differences in the surface mannoproteins of Candida albicans as revealed by monoclonal antibodies. Infection and Immunity 56: 601-606.

Towbin H, Staehelin T, Gordon J 1979 Electrophoretic transfer of proteins from polyacrylamide gels to nitrocellulose sheets: procedure and some applications. Proceedings of the National Academy of Sciences of the USA 76: 4350-4354.

Weinberg E D 1971 Role of iron in host-parasite interactions. Journal of Infectious Diseases 124: 401-410.

Weinberg E D 1984 Iron withholding: a defence against infection and neoplasia. Physiological Reviews 64: 65-102. 